Article

\title{
Exploratory Assessment of a Company's Due Diligence System against the EU Timber Regulation: A Case Study from Northwestern Russia
}

\author{
Maxim Trishkin ${ }^{1,2 *}$, Eugene Lopatin $^{3}$ and Timo Karjalainen ${ }^{1,3}$
}

1 Faculty of Science and Forestry, School of Forest Sciences, University of Eastern Finland, P.O. Box 111, Joensuu, Finland; E-Mail: timo.karjalainen@luke.fi

2 Faculty of Social Sciences and Business Studies, Department of Geographical and Historical Studies, University of Eastern Finland, P.O. Box 111, Joensuu, Finland E-Mail: maxim.trishkin@uef.fi

3 Natural Resources Institute Finland, P.O. Box 68, Joensuu, Finland; E-Mail: eugene.lopatin@luke.fi

* Author to whom correspondence should be addressed; E-Mail: maxim.trishkin@uef.fi; Tel.: +358-50-442-4266; Fax: +358-29-445-7316.

Academic Editors: Thomas Straka and Eric J. Jokela

Received: 3 November 2014 / Accepted: 14 April 2015 / Published: 22 April 2015

\begin{abstract}
This study uses a company's due diligence system (DDS) as an operational tool to ensure the origin of wood coming from northwestern Russia. The company exports a majority of its wood products to European Union (EU) countries, and its DDS consists of a statement of origin, geographical information, and field verification audits. Its DDS is assessed against the European Union Timber Regulation (EUTR). Enforcement of the EUTR began in March 2013 and is compulsory for all companies importing wood-based material from outside the EU. The DDS must contain three key components: access to information on operator's supply of timber or timber products placed on the market, a risk assessment, and a risk mitigation method. The workflow of the conformity assessment must include a literature review, statistical and field data collection, and further analysis of the requirements. Although enforcement of the EUTR began almost two years ago, there is little research on its implementation. This DDS system showed high functionality of its existing components corresponding with the general requirements of the standards developed by the Nature Ecology and People Consult (NepCon), a non-profit organization recognized as the monitoring organization by the European Commission. This wood origin system also meets the requirements of the Forest Stewardship Council (FSC) certification system, while
\end{abstract}


maintaining full harmonization with the EUTR legislation. However, major obstacles persist in implementation of legislation by EU member states, in terms of interpretation of requirements, prosecutions and fines, and the role of third-party evidence.

Keywords: DDS; EUTR; illegal logging; FSC; supply chain; risk assessment; mitigation

\section{Introduction}

\subsection{Illegal Logging in Russia}

Russia accounts for over $20 \%$ of the world's forests, but its share in the world forest products trade is below 4\%. Roundwood and semi-processed sawn wood comprise up to 54\% of its wood exports. The Russian domestic market consumed $61 \%$ of its forest sector production; the remaining 39\% was exported [1]. In 2010, key wood importers from Russia were European countries (37\%) and Asian countries (49\%), with other countries covering 14\% [2].

Russia saw many internal reforms after the Soviet period, including the decentralization of responsibilities to the regional level and the shifting of tenure rights from the leskhoz system (State Forest Management Units) to forest leaseholders for up to 49 years [3]. Russia joined the World Trade Organization (WTO) after 18 years of negotiations, which has made tax quotes clear and boosted the forestry economy of its biggest trading partner, the European Union (EU) [4]. Despite this, modern Russian forestry faces many challenges because regulations are poorly enforced; thus, there is little trust in them among the population [5]. Illegal logging is thus a significant consequence of poor enforcement of related regulations [6], though there is little reliable data on Russian crime in general. Thus, estimations of illegal logging in Russia vary by source. According to the State Forest Agency, illegal logging accounts for less than 1\% of total logged wood [7]. However, the World Widelife Fund (WWF) Russia and the World Bank estimate that up to $20 \%$ of extracted wood is illegal, reaching up to $50 \%$ in Siberia and the Russian Far East [8,9]. The difference in assessments is partly due to the absence of an official definition for illegal logging, different methods of accounting, and incompetence [10]. The existence of illegal logging nevertheless raises concerns of inefficient forest management and overexploitation $[11,12]$.

\subsection{Voluntary Market-Based Instruments}

Forest certification emerged as a concept to combat illegal logging and facilitate sustainable forest resource management in the 1990s [13]. Forest certification is seen by many experts worldwide [14-21] and in Russia [22-28] as a major tool to guarantee that a product comes from a well-managed forest. Presently, forest certification is spotty across the country. There are two main certification schemes operating in Russia: the Forest Stewardship Council (FSC) and the Russian National Council on Forest Certification (RNCFC), which is endorsed by the Programme for the Endorsement of Forest Certification (PEFC). The FSC prevails in Russian conditions and is strongly supported by non-governmental organizations (NGOs) [22]. Forest certification started its active phase in Russia in 2000 when the first FSC certificate was issued in the Altay region [29]. As of March 3, 2015, 40.22 million hectares of 
Russian forests are FSC certified and 452 certificates of chain of custody (COC) have been issued, including 233 certificates of controlled wood (CW) [30]. As of January 1, 2015, more than 2 million hectares of Russian forests are certified under PEFC standards with 27 COC certificates [31].

\subsection{Compulsory Instruments Applied in Russia}

Despite the rapid development of voluntary certification, it only covers $4 \%$ of productive forest or $20 \%$ of leased forest in the entire country [25]. Major wood processing companies operating in northwestern Russia export mainly to EU countries and represent $70 \%$ of wood consumption in the region [28,32]. Public procurement seems to be relying on forest certification, supplementing the recent European legislation related to wood origin [33]. Certification reduces the risk of imports with illegal origin [34]. Joint legislation similar to the Lacey Act in the United States and Australia's Prohibition Act was developed by EU countries to ensure that all wood products that are included within the EUTR's scope and imported from outside the EU are legal. Thus, Regulation (EU) 995/2010 from the European Commission was enforced in March 2013 and requires compulsory declaration of all wood imports coming from non-EU countries [35]. This act prohibits operators in the EU from placing illegally logged timber and products derived from illegal timber on the market. The EUTR and the Voluntary Partnership Agreements (VPA) work together under the EU Forest Law Enforcement, Governance and Trade (FLEGT) Action Plan, which sets out measures for the EU and its member states to tackle illegal logging [36]. The EUTR prohibits illegally logged timber on the EU market; EU operators must exercise a due diligence system (DDS) and maintain an up-to-date record system for suppliers and customers. Apart from the EUTR, the Russian government introduced Federal Law 415 in December 2013. It regulates relationships of wood trading outside of forests and requires accounting of total volumes of logged roundwood [37,38].

\subsection{Reasoning and objectives}

Operators placing timber on the EU market from outside the EU are responsible for the DDS, according to Article 6 [35]. It includes information concerning the operator's supply of timber or timber products placed on the market, risk assessment procedures for analysis, and evaluation and risk mitigation procedures that require verification. Naturally, Russian foresters must understand the "state of the art" in relation to the EUTR, especially when the regulation clearly outlines minimum requirements for third-party certification (e.g., FSC) or other third-party verification systems to be admitted as tools for the purposes of risk assessment and mitigation under the EUTR. Therefore, the suppliers of the European operators should at least provide information upon request or have a DDS system in place.

Russian forestry and thus the Russian wood trade are associated with illegal activities and corruption [5]. According to Transparency International, the Corruption Perception Index for Russia in 2014 was indexed as 27, indicating a high level of corruption risk in the country [39], which should be taken into account in the FSC CW risk assessment. This conclusion calls for an exploratory assessment of DDS under the EUTR, as Russia is a major supplier to the EU market. The practical implications of the EUTR are still not well known, and academic research in this field is slim [8,24]. Yet in Russia, its importance cannot be doubted. 
Moreover, several factors have an influence on wood exports in Northwestern Russia. Poor internal accounting, poor oversight of timber logging, and faking of timber documentation make the work harder for responsible timber companies. Irresponsible temporary "one-day" companies, which are small in size and work in remote areas, mix the wood and substitute its origin. They make it more difficult to track the legality of the origin of timber. Generally, wood exporters underestimate the weight of timber batches, consequently overestimating wood's density and underestimating its total volume.

The aim of this study is to perform an independent analysis of existing information in relation to suppliers' information, risk assessment, and risk mitigation, described above as parts of a DDS. An anonymous company operating in Russia chosen for the purpose of the present study has a DDS in place to ensure that only legally logged wood or products made of such wood enter its supply chain. This study's secondary aims are (1) analysis of the current DDS in the company and its basic elements based on data obtained from 2007 to 2011; (2) assessment of the company's risk assessment and risk mitigation procedures; and (3) suggestions for improving the DDS.

\section{Materials and Methods}

Northwestern (NW) Russia is the most important supplier of industrial roundwood to Europe, particularly to the Nordic countries. This region includes Arkhangelsk, Vologda, Karelia, Komi, Leningrad, Novgorod, Murmansk, Pskov, and Kaliningrad [32]. The proximity to European countries and export orientation of the operating companies played a key role in identification of the geographical scope of the research. An anonymous company with an international forestry background was chosen for a case study with NW Russia as its operational scope. The company we chose to analyze has more than 20 years of operational history in Russia. It also has a functioning DDS, which has been developed from the company's own wood tracking system, used since 1996. The company being studied exports an average of a few million cubic meters of roundwood annually from Russia to its head unit in the EU. The majority of the wood is pulpwood, as well as saw wood and firewood. In order to ensure the legality of wood originating from Russia, the company continuously improves its wood tracking system. It also holds an FSC COC/CW certificate valid from 2007. The company has tightened its requirements for wood material delivered from its suppliers to fulfill the requirements of the FSC COC/CW standards.

The forest resources of NW Russia are supplied not only to domestic markets but also to export markets, mainly in the form of roundwood. This means that suppliers should consider Regulation (EU) $995 / 2010$ in the course of business. The export orientation of the chosen company played a key role in its selection. The position of the studied company (under operator in Table 1) and its responsibility in relation to other key actors regarding Regulation (EU) 995/2010 can be found in Table 1.

Table 1. Responsibility and position of the studied company (operator) according to the EUTR [36].

\begin{tabular}{cc}
\hline Actor & Responsibility \\
\hline Operator & Maintenance, update, and evaluation of DDS (except DDS developed by MO). \\
\hline Competent authority (CA) & Control over EUTR implementation in EU member state, verification of \\
performance of MO.
\end{tabular}

Development, maintenance and evaluation on regular basis of MO's DDS;

Monitoring organization (MO) provision of DDS to operators, verification of DDS implementation by operators; reporting to $\mathrm{CA}$ in cases of operator noncompliance. 
Trader

Maintenance of basic information on its supplier and buyer to enable the traceability of timber and its products, provision of such data to CA upon request.

The company has its own wood tracking system, which consists of three main elements: statement of origin, geographic information system (GIS) mapping, and suppliers' databases, which covers suppliers' audits and logging site checks. Thus, the data collection included both revision of documentation (of those three elements) and results of field verifications from 2007 to 2011 . Analysis of the company's DDS could not be assessed against Regulation (EU) 995/2010 because it is framework legislation. Therefore, the existing publicly available standard by NEPCon, which acts as a monitoring organization, was used for further analysis. The standard FSC COC/CW report retrieved from the certification body's checklist was used. In addition, it was cross-checked with Annexes 1-3 of the LegalSouce standard, developed by NEPCon, which is designed to implement a DDS that enables the risk evaluation of wood or wood products and could be used to take appropriate mitigation measures [40]. Table 2 schematically classifies the key areas of the company's DDS in relation to the LegalSource standard.

Table 2. The key areas of the company's DDS and its components.

\begin{tabular}{cc}
\hline Areas of DDS & Components \\
\hline 1. Legal procedures and commitment & Official commitment to legal sourcing; Procedures; Self-performance \\
monitoring; Scope of supply chain
\end{tabular}

Due to research limitations, this article only covers the company's supply chain, risk assessment, and risk mitigation. The legal procedures and commitment were used as preconditions by the authors for these other three areas. Table 3 maps and recodes the initial information of the supply chain.

Table 3. Map and recoding of the initial information of the supply chain.

\begin{tabular}{cc}
$\begin{array}{c}\text { Number of Actors in } \\
\text { the Supply Chain }\end{array}$ & Explanation \\
\hline $1^{1}$ & $\begin{array}{r}1 \text { - The company that holds the harvesting rights (1), the company that performs logging } \\
(1), \text { and the company that transports and sells the material (1) are the same company }\end{array}$ \\
\hline $2=1^{2}$ and/or trader & $\begin{array}{r}\text { 2 - The company that holds the harvesting rights (1) is the company that transports and } \\
\text { sells the material (1) but not the company that performs logging (2) }\end{array}$ \\
\hline $3=1^{3}$ and/or trader(s) & $\begin{array}{r}3 \text { - The company that holds the harvesting rights (1) is not the company that performs } \\
\text { logging (2), which is the company that transports and sells the material (3) }\end{array}$ \\
\hline $4=1^{4}$ and/or trader(s) & $\begin{array}{r}\text { 4_The company that holds the harvesting rights (1), the company that performs logging } \\
\text { (2), and the company that transports and sells the material (3, 4) are each different }\end{array}$ \\
\hline
\end{tabular}

For risk assessment and risk mitigation, the information was collected based on verification of legal documents and records of supplier verification in the field.

\section{Results}

\subsection{Supply Chain}


The company under study procures most of its wood from its suppliers in NW Russia. Detailed and accurate information is required from companies that deliver wood to describe the whole supply chain. The company requires its suppliers through signed commitment on legal sourcing to conform to national and international principles of sustainable development through contract terms of agreement, similarly to FSC CW risk assessment. If a supplier fails to provide clarification of the wood origin in specific areas (e.g., strictly protected forest areas (SPFAs)), the company reserves the right to reject wood or terminate the deliveries. In field audits, the company prioritizes, in order, new suppliers, suppliers delivering bigger volumes of wood than average suppliers, non-FSC certified suppliers, suppliers that constantly delay legal documentation, suppliers with more than 2 actors in their supply chain, and suppliers operating nearby high conservation value forests (HCVFs) as defined in the FSC certification standards.

The company has implemented an information system to track the origin of wood. It is incorporated into a quality assurance system following International Standard Organization (ISO) 9001 and an environmental management system (EMS) according to ISO 14001. It consists of three main elements: statement of origin, database and GIS mapping, and field verifications. A written statement of origin in the form of self-declaration from the supplier is a mandatory part of each wood supply contract. The information has the following structure: name and contact details of the supplier (seller); contract number; method of delivery; names and contact details of sub-suppliers; volume of delivered timber in $\mathrm{m}^{3}$;

GIS-based information, including location of logging sites (region, forest district, compartment, and sub-compartment); and loading terminal or port, including code number (and location of sawmill for chip suppliers). Thus, it provides explicit information on the supply chain in terms of the number of actors involved for further risk assessment and mitigation, as presented in Table 4.

Table 4. Supply chains according to number of actors involved (2007-2011).

\begin{tabular}{cccccccccccc}
\hline \multirow{2}{*}{ Actors of the Supply Chain } & \multicolumn{2}{c}{$\mathbf{2 0 0 7}$} & \multicolumn{2}{c}{$\mathbf{2 0 0 8}$} & \multicolumn{2}{c}{$\mathbf{2 0 0 9}$} & $\mathbf{2 0 1 0}$ & \multicolumn{2}{c}{$\mathbf{2 0 1 1}$} \\
\cline { 2 - 11 } & $\mathbf{N} *$ & $\mathbf{\%}$ & $\mathbf{N} *$ & $\mathbf{\%}$ & $\mathbf{N} *$ & $\mathbf{\%}$ & $\mathbf{N} *$ & $\mathbf{\%}$ & $\mathbf{N} *$ & $\mathbf{\%}$ \\
\hline $1^{1}$ & 28 & 26 & 28 & 29 & 22 & 32 & 20 & 26 & 21 & 27 \\
$2=1^{2}$ and/or trader & 53 & 49 & 51 & 53 & 34 & 49 & 42 & 55 & 33 & 42 \\
$3=11^{3}$ and/or trader(s) & 23 & 21 & 17 & 18 & 10 & 14 & 12 & 16 & 22 & 28 \\
$4=1$ & 4 and/or trader(s) & 5 & 5 & - & - & 3 & 4 & 2 & 3 & 3 & 4 \\
Total & 109 & 100 & 96 & 100 & 69 & 100 & 76 & 100 & 79 & 100 \\
\hline
\end{tabular}

* $\mathrm{N}$-Number of supply chains. (-) — Absence of the actors in the supply chain

As can be observed from Table 4, most supply chains have at least two actors involved in the procurement of wood material. Less than $30 \%$ of supply chains involve only one company. The proportion of 3 -actor supply chains increased from $21 \%$ to $28 \%$ between 2007 and 2011 . Note that the total number of supply chains decreased during the study period, which was mainly associated with the shift toward bigger suppliers with bigger volumes supplied.

The company has developed a GIS system with georeferenced coordinates of the suppliers' logging sites in NW Russia and keeps its database up to date. Changes entered into the database automatically amend the initial map. The current GIS system covers wood deliveries by rail, road, and water. Additionally, the company has a list of all the SPFAs in NW Russia, including official SPFAs and planned SPFAs without official status. The latter are better known as moratorium territories proposed to 
be set aside by NGOs or other environmental activists. The company declines to purchase wood from both categories of protection status, even though forest industrial companies officially allow logging on SPFAs without official status by Russian legislation. However, active concern with moratorium territories is part of National CW FSC risk assessment and is taken into account by the company in Russia [41].

The results presented below (Table 5) of the field audit in the Leningrad region were carried out as part of an annual auditing routine that is based on a sample similar to Annex 3 of the FSC CW standard [42] in NW Russia. The Leningrad region was chosen for model auditing because the majority of suppliers are from this area. The audits were performed during summer 2012. Two people represented the audit team: a company specialist and an external person who was recording the audit process and its results.

Table 5. Forest site audits at the forest management unit level.

\begin{tabular}{|c|c|c|c|c|c|c|c|}
\hline $\mathbf{N}$ & Region & $\begin{array}{c}\text { Location Forest } \\
\text { District (lesnichestvo) }\end{array}$ & $\begin{array}{c}\text { GPS } \\
\text { Coordinates }\end{array}$ & Comp. (kvartal) * & $\begin{array}{c}\text { Subcomp ** } \\
\text { (vydel) }\end{array}$ & Area, ha & Type of Felling \\
\hline 1 & Leningrad & Dymovskoye & $\begin{array}{l}\text { N: } 61^{\circ} 14.627^{\prime} \\
\text { E: } 29^{\circ} 21.340^{\prime}\end{array}$ & 16 & $1,2,9,10,11$ & 26.5 & $\begin{array}{l}\text { Clear-cut } \\
\text { (sanitary) }\end{array}$ \\
\hline 2 & Leningrad & Dymovskoye & $\begin{array}{l}\mathrm{N}: 61^{\circ} 08.539^{\prime} \\
\mathrm{E}: 29^{\circ} 22.554^{\prime}\end{array}$ & 251 & $24,25,26,27$ & 20.1 & $\begin{array}{l}\text { Clear-cut } \\
\text { (sanitary) }\end{array}$ \\
\hline 3 & Leningrad & Dymovskoye & $\begin{array}{l}\mathrm{N}: 61^{\circ} 08.583^{\prime} \\
\mathrm{E}: 29^{\circ} 22.252^{\prime}\end{array}$ & 262 & $\begin{array}{c}7,13,14,15,22 \\
28,31,34,36\end{array}$ & 28.8 & $\begin{array}{l}\text { Clear-cut } \\
\text { (sanitary) }\end{array}$ \\
\hline 4 & Leningrad & Dymovskoye & $\begin{array}{l}\text { N: } 61^{\circ} 07.990^{\prime} \\
\text { E: } 29^{\circ} 920.930^{\prime}\end{array}$ & 265 & 1 & 31.2 & $\begin{array}{l}\text { Clear-cut } \\
\text { (sanitary) }\end{array}$ \\
\hline 5 & Leningrad & Dymovskoye & $\begin{array}{l}\mathrm{N}: 61^{\circ} 09.401^{\prime} \\
\mathrm{E}: 29^{\circ} 23.373^{\prime}\end{array}$ & 144 & $18,24,31$ & 57.8 & $\begin{array}{l}\text { Clear-cut } \\
\text { (sanitary) }\end{array}$ \\
\hline 6 & Leningrad & Prigorskoye & $\begin{array}{l}\text { N: } 59^{\circ} 38.304^{\prime} \\
\text { E: } 33^{\circ} 34.794^{\prime}\end{array}$ & 35 & $3,9,18$ & 26.8 & $\begin{array}{c}\text { Commercial } \\
\text { thinning, } 20 \% \\
\text { remove }\end{array}$ \\
\hline 7 & Leningrad & Prigorskoye & $\begin{array}{l}\text { N: } 59^{\circ} 38.341^{\prime} \\
\text { E: } 33^{\circ} 36.807^{\prime}\end{array}$ & 36 & 7 & 9.0 & $\begin{array}{c}\text { Commercial } \\
\text { thinning, } 15 \% \\
\text { remove }\end{array}$ \\
\hline 8 & Leningrad & Ozerskoye & $\begin{array}{l}\text { N: } 59^{\circ} 52.542^{\prime} \\
E: 34^{\circ} 16.685^{\prime}\end{array}$ & 73 & 37 & 13.5 & Clear-cut \\
\hline 9 & Leningrad & Turgoshskoye & $\begin{array}{l}\text { N: } 59^{\circ} 23.532^{\prime} \\
\text { E: } 35^{\circ} 06.259^{\prime}\end{array}$ & 40 & 26 & 5.6 & $\begin{array}{c}\text { Commercial } \\
\text { thinning }\end{array}$ \\
\hline 10 & Leningrad & Turgoshskoye & $\begin{array}{l}\text { N: } 59^{\circ} 22.957^{\prime} \\
\text { E: } 35^{\circ} 06.764^{\prime}\end{array}$ & 40 & 58 & 6.8 & $\begin{array}{c}\text { Commercial } \\
\text { thinning }\end{array}$ \\
\hline 11 & Leningrad & Shugozerskoye & $\begin{array}{l}\text { N: } 59^{\circ} 55.049^{\prime} \\
\text { E: } 34^{\circ} 00.468^{\prime}\end{array}$ & 49 & 33 & 5.5 & $\begin{array}{c}\text { Commercial } \\
\text { thinning }\end{array}$ \\
\hline 12 & Leningrad & Shugozerskoye & $\begin{array}{l}\text { N: } 59^{\circ} 55.440^{\prime} \\
\text { E: } 34^{\circ} 02.220^{\prime}\end{array}$ & 50 & 30 & 4.8 & $\begin{array}{l}\text { Commercial } \\
\text { thinning }\end{array}$ \\
\hline 13 & Leningrad & Shugozerskoye & $\begin{array}{l}\text { N: } 59^{\circ} 54.630^{\prime} \\
\text { E: } 33^{\circ} 55.432^{\prime}\end{array}$ & 158 & 3 & 12.6 & Clear-cut \\
\hline 14 & Leningrad & Shugozerskoye & $\begin{array}{l}\text { N: } 59^{\circ} 53.730^{\prime} \\
\text { E: } 33^{\circ} 54.603^{\prime}\end{array}$ & 157 & 70,71 & 8.2 & Clear-cut \\
\hline 15 & Leningrad & Shugozerskoye & $\begin{array}{l}\text { N: } 59^{\circ} 55.049^{\prime} \\
\text { E: } 33^{\circ} 54.966^{\prime}\end{array}$ & 156 & 71 & 10.3 & Clear-cut \\
\hline
\end{tabular}


* Comp. (kvartal) - Compartment is a management unit represented by square or rectangular shape, with size of $0.5 \times 0.5 \mathrm{~km}, 1 \times 1 \mathrm{~km}, 2 \times 2 \mathrm{~km}$ etc. depending on accuracy of forest inventory (in Siberia, partly based on natural boundaries). ** Subcomp (vydel)—Sub-compartment is forest stand with similar characteristics normally described by irregular shape (due to natural boundaries).

The 15 forest sites investigated in the Leningrad region were logged in accordance with the requirements of Russian forest legislation based on cross-verification with official documentation, and were mapped with a GIS application that verified they were not within the official SPFAs or moratorium territories.

The company performs annual field audits of its suppliers on a sample basis similarly to the FSC-accredited certification body that are responsible for third-party audits according to Annex 3 of the FSC CW standard [42]. Each supplier is audited at least once every 5 years. In addition to regular sampling of the audits, the performance of new suppliers and suppliers with repeated non-conformities is verified as a first priority. Table 6 represents the statistics of such audits for the procurement area of NW Russia.

Table 6. Number and timing of field audits of the company's suppliers.

\begin{tabular}{ccccccccccccc}
\hline \multirow{2}{*}{ Timing of the Audit } & \multicolumn{3}{c}{$\mathbf{2 0 0 7}$} & \multicolumn{2}{c}{$\mathbf{2 0 0 8}$} & \multicolumn{2}{c}{$\mathbf{2 0 0 9}$} & $\mathbf{2 0 1 0}$ & \multicolumn{2}{c}{$\mathbf{2 0 1 1}$} \\
\cline { 2 - 12 } & $\mathbf{N} *$ & $\mathbf{\%}$ & $\mathbf{N} *$ & $\mathbf{\%}$ & $\mathbf{N} *$ & $\mathbf{\%}$ & $\mathbf{N} *$ & $\mathbf{\%}$ & $\mathbf{N} *$ & $\mathbf{\%}$ \\
\hline Delineated stand before the logging & 9 & 4 & 6 & 3 & 3 & 2 & - & - & 1 & 1 \\
During logging & 115 & 50 & 70 & 31 & 35 & 26 & 46 & 30 & 62 & 36 \\
After logging (before transportation) & 105 & 46 & 151 & 67 & 8 & 6 & 57 & 38 & 52 & 31 \\
After logging and transportation & - & - & - & - & 89 & 66 & 49 & 32 & 55 & 32 \\
Total & 229 & 100 & 227 & 100 & 135 & 100 & 152 & 100 & 170 & 100 \\
\hline
\end{tabular}

* $\mathrm{N}$-Number of field audits. (-) — Absence of the field audits.

According to Table 6, the majority of the audits in 2007 and 2008 were performed during and after logging but before transportation. In 2009, most were done after logging and transportation. In 2010 and 2011, field checks were equally distributed during logging, after logging but before transportation, and after transportation. Only a few site verifications ever took place before logging. The shift in timing for logging and post-logging audits resulted from poor communication between the auditor and the suppliers. However, timing of the field audit is essential in this respect, as it is advisable to carry out the field checks during the logging operation, especially for suppliers that involve more actors in the supply chain (Table 4).

The nonconformities identified by the auditor during the supplier's verifications are divided into five categories: legal documentation, quality of preparation before logging, quality of logging operations, fire safety and waste handling, and work safety. The company defines the categories based on its own experience and the requirements of the FSC CW standard. Table 7 shows the distribution of detected nonconformities according to defined categories in 2007-2011.

Table 7. Nonconformities detected during the field verification.

\begin{tabular}{cccccccccccc}
\hline \multirow{2}{*}{ Categories of NC } & \multicolumn{2}{c}{$\mathbf{2 0 0 7}$} & \multicolumn{1}{c}{$\mathbf{2 0 0 8}$} & \multicolumn{2}{c}{$\mathbf{2 0 0 9}$} & \multicolumn{2}{c}{$\mathbf{2 0 1 0}$} & \multicolumn{2}{c}{$\mathbf{2 0 1 1}$} \\
\cline { 2 - 12 } & $\mathbf{N} *$ & $\mathbf{\%}$ & $\mathbf{N} *$ & $\mathbf{\%}$ & $\mathbf{N} *$ & $\mathbf{\%}$ & $\mathbf{N} *$ & $\mathbf{\%}$ & $\mathbf{N} *$ & $\boldsymbol{\%}$ \\
\hline Legal documentation & 3 & 3 & 10 & 8 & 4 & 5 & 25 & 24 & 10 & 17 \\
Preparation work before logging & 10 & 9 & 17 & 14 & 22 & 27 & 7 & 7 & 11 & 18
\end{tabular}




\begin{tabular}{ccccccccccc} 
Logging operations & 19 & 18 & 47 & 38 & 26 & 32 & 27 & 26 & 4 & 7 \\
Fire safety \& waste handling & 2 & 2 & 5 & 4 & 15 & 18 & 22 & 21 & 15 & 25 \\
Work safety & 74 & 69 & 44 & 36 & 15 & 18 & 22 & 21 & 20 & 33 \\
Total & 108 & 100 & 123 & 100 & 82 & 100 & 103 & 100 & 60 & 100 \\
\hline
\end{tabular}

$* \mathrm{~N}$-Number of detected nonconformities.

As can be observed from Table 7, almost $70 \%$ of nonconformities in 2007 were related to work safety, whereas during 2008-2011 this figure decreased to $30 \%$ on average. At the same time, violations in relation to legal documentation increased from 3\% to $17 \%$ during the 5-year period. Poor-quality preparation work increased from $9 \%$ to $18 \%$ during the same period. Quality of logging operation increased, as indicated by a decrease in the relative incidence of corresponding nonconformities from $18 \%$ to $7 \%$. The nonconformities in terms of fire safety, waste handling, and work safety are beyond the EUTR requirements but are essential to a complete assessment of wood origin. Thus, the number of nonconformities on fire safety and waste handling increased from $2 \%$ to $25 \%$. On the contrary, nonconformities on work safety decreased from $69 \%$ to $33 \%$. Specific violations in terms of categories of nonconformities are presented in Table 8 .

Table 8. Specification of noncompliance in relation to categories.

\begin{tabular}{|c|c|c|c|c|c|c|}
\hline \multirow{2}{*}{ Categories of $\mathrm{NC}$} & \multirow{2}{*}{ Type of Noncompliance } & \multicolumn{5}{|c|}{ Frequency } \\
\hline & & 2007 & 2008 & 2009 & 2010 & 2011 \\
\hline \multirow{3}{*}{ Legal documentation } & Absence of technological map & 2 & 6 & 4 & 13 & 7 \\
\hline & Absence of statement of origin & 1 & 4 & $-*$ & 7 & - \\
\hline & Absence of forest declaration/agreement & - & - & - & 5 & 3 \\
\hline \multirow{3}{*}{$\begin{array}{c}\text { Preparation work } \\
\text { before logging }\end{array}$} & Absence of logging pole & 4 & 4 & 3 & - & 4 \\
\hline & Absence of data on logging pole & 6 & 13 & 3 & 5 & 4 \\
\hline & Illegibility of data on logging pole & - & - & 16 & 2 & 3 \\
\hline \multirow{8}{*}{ Logging operations } & Soil damage & 12 & 5 & 13 & 14 & 4 \\
\hline & Absence of set-aside areas & 3 & 39 & - & - & - \\
\hline & Poor quality and/or number of remaining young trees & 4 & - & - & - & - \\
\hline & Absence or insufficient number of seed trees & - & 2 & 2 & 12 & - \\
\hline & Exceedance of logging limits & - & 1 & - & - & - \\
\hline & High stumps & - & - & 3 & - & - \\
\hline & Injuries on remaining stems & - & - & 8 & - & - \\
\hline & Inappropriate clearance & 1 & - & - & 1 & - \\
\hline \multirow{6}{*}{$\begin{array}{c}\text { Fire safety \& } \\
\text { waste utilization }\end{array}$} & Absence of fire extinguishing equipment & 1 & 2 & - & - & - \\
\hline & Usage of inappropriate refueling equipment & - & 1 & 9 & 1 & 2 \\
\hline & Industrial litter & - & 1 & 6 & 19 & 9 \\
\hline & Inadequate knowledge of fire safety rules & - & 1 & - & - & 2 \\
\hline & Oil spills & - & - & - & 1 & 2 \\
\hline & Inappropriate machinery maintenance & - & - & - & 1 & - \\
\hline \multirow{4}{*}{ Work safety } & Absence of warning sign, e.g., "Logging Ahead" & 65 & 40 & 14 & 17 & 16 \\
\hline & Absence of personal safety equipment & 6 & - & - & 2 & 3 \\
\hline & Disuse of personal safety equipment & 3 & 4 & 1 & 3 & 1 \\
\hline & Totals & 108 & 123 & 82 & 103 & 60 \\
\hline
\end{tabular}

(-)-Absence of noncompliance in relation to categories. 
According to Table 8, the most frequent legal violation is the absence of a technological map at a forest site $(n=32)$. For preparation work, the most frequent violation is the absence of data on the logging pole $(n=31)$. Soil damage $(n=48)$ is the predominant violation during logging. Littering $(n=35)$ is a key violation in fire safety and waste utilization. In the work safety category, the largest problem is the absence of a warning sign $(n=152)$.

Supply-level information (e.g., a single batch/load) is fully covered in transport documents and incoming invoices from suppliers. Due to a company requirement, none of the supply could be delivered without information being fully provided on transport and invoice documents.

\subsection{Risk Assessment}

Risk assessment is a part of the company's DDS system. It takes into account the company's compliance with applicable legislation, avoidance of illegal harvesting, and armed conflicts in relation to any sanctions imposed by United Nations Security Council on timber imports and exports and supply-chain complexity in accordance with Article 6, 1b of Regulation (EU) 995/2010. The chosen company has held a valid FSC COC/CW certificate since 2007, so it has adequate experience and has implemented appropriate procedures to show that compliance with applicable legislation is assured. The statement of origin is a key document that verifies the origin of the procured material and species involved. A responsible manager in the company cross-checks any sanctions imposed by the United Nations Security Council and EU Council on timber imports and exports. The access to information on the operator's supply chain also describes the complexity of the supply chain. All the information is entered into the company's database. Therefore, the company manager responsible for risk assessment has extensive information and a delivery route to complete that assessment. Risk assessment in practice is a combination of a desk audit with additional evidence collected from documents, interviews, and field audits.

\subsection{Risk Mitigation}

Mitigation measures are a direct reflection of risk assessment. The company provides its suppliers with written feedback on risk assessment in the form of corrective action. After that, the company verifies if the noncompliance has been addressed and implemented. The company begins to practice the mitigation measures with cross-checks of existing information to avoid over-logging, logging beyond allocated borders, use of forbidden tree species, and use of forbidden cutting technology (only verifiable if field verification is applied). The suppliers' database contains information used to implement measures and follow controls. The database's information on suppliers contains four sections: initial information, contract details, additional information, and historical records. The contract on delivery provides a direct link to any audit undertaken in the company and statement of origin relevant for the chosen period. It allows allocating of an additional audit for the suppliers if the effect of the measures has not been sufficient. Initial information includes the supplier's contract details and contract's period of validity. Contract details include timber assortment, the total amount of timber delivered, and its price level. The additional information section allows notification of specific conditions not covered in the contract. The historical records provide valuable references to contract amendments and price differences. In addition, 
the supplier signs the declaration on adoption of the FSC policy requirements [43] and its implementation. Control of risk mitigation is determined systematically, which is reflected in identified measures. If the supplier violates the contract's conditions or does not fulfill FSC policy requirements in the company's policy sections [43], the contract is terminated without further notice. It is also important to note that any contract is terminated if a statement of origin is not delivered one month prior to the supply period. 


\section{Discussion}

Many private forestry companies procure roundwood of questionable legality. They have developed their own tracking systems to receive proof of legal origin for purchased wood. Large corporations especially emphasize this so-called "wood-flow control" in their management, which makes their operations more efficient in finding the optimum balance between guaranteeing a steady supply of raw material and maintaining storage capacity at economically feasible levels [44]. Even though such systems may not have been installed with the aim of proof of legality, they are a good basis upon which supply chain systems can be developed.

Less than $30 \%$ of supply chains to the company involve only one actor, or direct supply organized without any intermediate party involved. About 50\% of supply chains in the 2007-2011 period involved two actors, and $20 \%$ involved more than two. This increases the risk of substitution of raw material while changing the ownership of material from one supplier to another, even though the declared volumes might be correct. The company has discussed this widely as a potential threat to DDS and is well aware that its FSC certificate does not improve the situation, as the proportion of FSC-certified input materials is relatively low compared to the total volume of procured materials. In Russian national wood risk assessment, three out of five FSC controlled wood (CW) categories are considered unspecified risks [41], as presented in Table 9.

Table 9. FSC Controlled wood risk assessment for the Russian Federation.

\begin{tabular}{|c|c|c|c|c|}
\hline $\mathbf{N}$ & Controlled Wood Categories & Scale of Assessment & Number of Indicators & Risk Level \\
\hline \multirow{2}{*}{1} & \multirow{2}{*}{ Illegally harvested wood } & National & 6 & \multirow{2}{*}{ Unspecified } \\
\hline & & Regional & 1 & \\
\hline \multirow{2}{*}{2} & Wood harvested in violation of traditional & National & 8 & \multirow{2}{*}{ Unspecified } \\
\hline & and civil rights & Regional & 1 & \\
\hline \multirow{2}{*}{3} & Wood harvested in HCVFs threatened by & National & 2 & \multirow{2}{*}{ Unspecified } \\
\hline & management activities & Regional & 7 & \\
\hline \multirow{2}{*}{4} & Wood harvested in forests being converted & National & 2 & \multirow{2}{*}{ Low } \\
\hline & to plantations or non-forest use & Regional & 0 & \\
\hline \multirow{2}{*}{5} & Wood from forests with genetically modified & National & 3 & \multirow{2}{*}{ Low } \\
\hline & trees & Regional & 0 & \\
\hline
\end{tabular}

Two of these three categories of CW graded with unspecified risk mainly deal with assessment on a national scale, whereas the CW category concerning HCVF mainly deals with regional risk assessment and could be assessed more locally. This creates an imbalance and generalization of measures in relation to illegally logged wood, which is hard to address.

When it comes to the control of suppliers for three categories of CW with unspecified risk, the company constantly updates list and its boundaries of SPFAs with official status and moratorium territories. All the suppliers' logging sites are cross-verified with a GIS map, and traditional and civil rights are assured through communication with stakeholders (NGOs, labor unions, employees, union of indigenous people) on a constant basis.

The company's field audits focus on five main categories that are part of a DDS: legal documentation, preparation work before logging, logging operations, fire safety and waste handling, and work safety. 
However, according to LegalSource Standard (Annex 1) [40], legal compliance at the forest level shall include the following categories under the timber harvesting section: timber harvesting regulation, protected sites and species, environmental requirements, health and safety, and legal employment. Thus, it is advisable to adjust the existing DDS to the existing requirements of the EUTR, which are reflected in the LegalSource standard, in order to harmonize the basic requirements.

When it comes to the timing of the audit, the most suitable time is during the logging operation, as the auditor is able to verify all five categories in Annex 1 [40]. At the same time chosen for the analysis, the company verifies only $25 \%-50 \%$ of audited suppliers during the logging operations. A substantial number of the field audits were carried out after logging operations. For instance, the company recorded that during 2007-2011 about 50\% of nonconformities were found in relation to fire and work safety. The noncompliance related to these categories could not be fully assessed when the audit was timed after logging operations.

Several years ago, the Russian government drafted an online tool called the "Joint State-Automated Information System of Wood Flow Accounting and Its Trading" (the Russian abbreviation is EGAIS) to enhance state control of the wood trade. It has been developed in line with Regulation (EU) 995/2010 and was aimed to harmonize the different legislation. This was one of the outcomes of Russian Federal Law 415, adopted in December 2013, which has already been partly enforced since July 2014 [45]. However, one major drawback of the accounting system is that it has only been applied to unprocessed wood up to now - mainly roundwood, which narrows its applicability. The FSC has made many efforts to comply with EUTR requirements and harmonize the FSC and EUTR systems. It has recently launched an online claim platform (OCP), which helps to streamline the validation of FSC claims and make the system more able to scale and adapt [46]. However, the OCP tool is only aimed at tracking records and volumes of FSC-certified suppliers, thus limiting its applicability to other type of materials.

The detailed results regarding the conformance of the company's DDS with EUTR requirements are presented in Table 10.

Table 10. Conformance of the company's DDS with the EUTR requirements.

\begin{tabular}{ccc}
\hline Areas of DDS & Components & Conformance \\
\hline \multirow{4}{*}{ 1. Legal procedures and commitment } & Official commitment to legal sourcing & $+/-$ \\
& Procedures & +- \\
& Self-performance monitoring & +- \\
& Scope of supply chain & +- \\
\hline \multirow{2}{*}{ 2. Supply chain } & Forest management level & + \\
& Supplier level & + \\
& Supply level & + \\
3. Risk assessment & Documentation on legality & + \\
& Information on suppliers & + \\
\hline & Species & + \\
4. Risk mitigation & Volumes & + \\
\hline "+" means the component is included into DDS and successfully implemented, "+/-" means the component \\
could not be fully verified from available information, and "-" means the component is absent or not verifiable \\
from available information.
\end{tabular}


The analyzed company put significant effort into developing its DDS, which is harmonized with the requirements of FSC $\mathrm{COC} / \mathrm{CW}$ standards and aimed to be in line with EUTR requirements. The company's DDS has been fully assessed in terms of the company's supply chain, risk assessment, and risk mitigation. Legal procedures and commitments have been used as prerequisites for three key areas and partly assessed, since the actual format and content of that component were not self-evident from the standard developed by NepCon [40]. Even though the table presented above is generic, it represents the overall state-of-art of the company and its level of DDS system readiness with regard to EUTR requirements.

\section{Conclusions}

Most forestry companies in Russia do not have complete systems to track the origin of wood, except for certified wood. Widespread illegal logging and wood trading have resulted in rapid and catastrophic deterioration of the environment, which has hindered the development of the timber-processing industry and tarnished Russia's image in the international wood market. Thus, promoting the good practices of a successfully functioning DDS among forestry companies in Russia could improve the illegal logging situation in the country. It would positively affect the transparency of supply chains and improve the image of Russian export-oriented companies. Simultaneously, it may simplify the reporting of Russian companies to the EGAIS wood accounting system within Russia. However, companies with larger operational scales implement similar DDSs more promptly; however, smaller companies might face a lack of human and technical resources. Moreover, it should be noted that companies that hold, for instance, an FSC certificate, could achieve compliance with the EUTR more efficiently than non-certified companies [28].

The studied company is a major exporter of wood material, mainly in the form of roundwood, to EU countries. Its system to ensure the legality of wood origin functions far beyond the Russian legislation, and additional requirements are set to ensure the legality of its exports to EU countries and elsewhere. Nevertheless, the analysis of the company's DDS system revealed a discrepancy in the structure of the functional components, compared to those developed by NepCon in the standard. This case study points out the key drawback of the system and suggests how the system could be improved. Thus, properly choosing the timing of field verifications for the company's suppliers is essential in order to cover the whole set of requirements. Greater emphasis should be put on communication with the suppliers, in order to avoid any confusion about corrective measures and their control from the operator's side. However, major obstacles persist in the implementation of legislation by EU member states on the technical effectiveness of DDSs in relation to the EUTR. Moreover, prosecution remains unclear, the fine system is not unified, and the role of third-party evidence is still unclear.

The enforcement of measures in each EU member state, with regards to operators and traders, is rather heterogeneous. Eleven states (Austria, Denmark, Croatia, Germany, Cyprus, Czech Republic, Portugal, Luxembourg, Slovenia, United Kingdom, and Italy) have enforced specific national legislation. Eight states (Belgium, Bulgaria, Finland, France, Ireland, Poland, Romania, and Sweden) have only drafted it. One state (Netherlands) has an interim regulation in the process of adoption, and seven states (Estonia, Lithuania, Greece, Malta, Hungary, Slovakia, Spain) have no legislation even drafted. Latvia is the only EU member state that has not communicated its activities since August 2013 [47]. 
The company's system could be of great interest to stakeholders and decision makers involved in the implementation of DDSs in Russia and elsewhere. There is a need to further study how to increase their awareness of the system. The EUTR is major tool to combat illegal timber on European markets, but its enforcement at full speed and the heterogeneity of enforcement among EU member states are inhibiting the process.

\section{Acknowledgments}

The authors are grateful to the anonymous company that provided the data for the study and particularly to M.Y. and I.S., who were supportive and enthusiastic about the process. We would also like to thank to company's suppliers, who agreed to field verification and providing legal documentation. The School of Forest Sciences of the University of Eastern Finland provided the funding to Mr. Maxim Trishkin.. This research was carried out within Contesting Bioenergy Governance project (14878) funded by Academy of Finland. The Ministry of Education and Science of the Russian Federation, project 14.B37.21.1248, supported the work of Dr. Eugene Lopatin. Both researchers are also grateful to the Baltic Sea Region 2007-2013 project "Baltic Landscapes" partly financed by the EU (European Regional Development Fund and European Neighborhood and Partnership Instrument), www.modelforest.fi, and the ENPI Karelia project "Integrated landscape planning for sustainable use of nature resources and maintaining biodiversity" KA528 (funded by the governments of Finland and Russia, as well as the EU ENPI Programme, www.karlands.ru). The valuable suggestions made by two anonymous reviewers are gratefully acknowledged.

\section{Author Contributions}

Trishkin M. collected the field data, analyzed it in accordance with chosen methodology and wrote the manuscript; Lopatin E. and Karjalainen T. provided initial feedback and continuous support during the article implementation.

\section{Conflicts of Interest}

The authors declare no conflicts of interest. The opinions expressed herein are those of the authors and do not necessarily reflect the views of other parties.

\section{References}

1. Russian Forestry Outlook, 2012. The Russian Federation Forest Sector Outlook Study to 2030. Available online: http://www.fao.org/docrep/016/i3020e/i3020e00.pdf (accessed on 15 May 2013).

2. Rosstat. Tamozhennaya statistica vneshney torgovli Rossiyskoy Federatsii [Customs statistics of external trade of the Russian Federation]. Compendium 2011, 1, 1-359.

3. Torniainen, T. Institutions and forest tenure in the Russian forest policy. Diss. For. 2009, 95, 64.

4. IFI (International Forest Industries). Russia Finally Joins WTO. Available online: http://www.internationalforestindustries.com/2012/01/12/russia-finally-joins-wto/ (accessed on 18 January 2012). 
5. Pappila, M. Forest certification and trust-Different roles in different environments. For. Policy Econ. 2013, 31, 37-43.

6. Teplyakov, V.; Grigoriev, A. 2006. Forest Governance and Illegal Logging: Improving legislation, and Interagency and Inter-stakeholder Relations in Russia. IUCN, Office for the Commonwealth of Independent States. Available online: www.iucn.org/about/work/programmes/forest/fp_resources/ $\mathrm{fp} \_$resources_publications/fp_resources_thematic_pubs/fp_resources_governance/?703/ForestGovernance-and-Illegal-Logging (accessed on 18 March 2013).

7. Rosleskhoz, 2011. Federal Forest Agency. Available online: http://www.rosleshoz.gov.ru/ opendata/ (accessed on 13 May 2014).

8. World Bank. Sovershenstvovaniye Pravoprimeneniya I Upravleniya v Lesnom Sektore Rossiyskoy Federatsii. Uchebnoye Posobije [Improvement of Law Enforcement and Forest Sector Management of the Russian Federation]; Work Book: Moscow, Russia, 2011.

9. WWF. WWF Rossii. Systemy Otslezhivaniya Proishozhdeniya Drevesiny v Rossiyskoy Federatsii: Opyt Lesopromyshlennyh Kompaniy I Organov Upravleniya Lesami. Analiticheskiy otchyot [WWF Russia. System of the Traceability of the wood Origin in the Russian Federation: Experience of Forest Industry Companies and Forest Management Bodies]; Analytical Report: Moscow, Russia, 2011; Available online: http://www.wwf.ru (accessed on 13 October 2013).

10. Food and Agricultural Organization (FAO), 2013. The Russian Federation Forest Sector. Outlook study to 2030. Available online: http://www.fao.org/docrep/016/i3020e/i3020e00.pdf (accessed on 21 October 2013).

11. Li, R.; Buongiorno, J.; Turner, J.A.; Zhu, S.; Prestemon, J. Long-term effects of eliminating illegal logging on the world forest industries, trade, and inventory. For. Policy Econ. 2008, 10, 480-490.

12. Moiseyev, A.; Solberg, B.; Michie, B.; Kallio, I.; Maarit, A. Modeling the impacts of policy measures to prevent import of illegal wood and wood products. For. Policy Econ. 2010, 12, 24-30.

13. Cubbage, F.; Harou, P.; Sills, E. Policy instruments to enhance multi-functional forest management. For. Policy Econ. 2007, 9, 833-851.

14. Cashore, B.; Auld, G.; Newsom, D. Forest certification (eco-labeling) programs and their policy-making authority: Explaining divergence among North American and European case studies. For. Policy Econ. 2002, 5, 225-247.

15. Kallas, A. Public forest policy making in post-Communist Estonia. For. Policy Econ. 2002, 4, 323-332.

16. Nebel, G.; Quevedo, L.; Jacobsen, J.B.; Helles, F. Development and economic significance of forest certification: The case of FSC in Bolivia. For. Policy Econ. 2005, 7, 175-186.

17. Newsom, D.; Bahm, V.; Cashore, B. Does forest certification matter? An analysis of operation-level changes required during the SmartWood certification process in the United States. For. Policy Econ. 2006, 9, 197-208.

18. Cubbage, F.; Diaz, D.; Yapura, P.; Dube, F. Impacts of forest management certification in Argentina and Chile. For. Policy Econ. 2010, 12, 497-504.

19. Howard, P.H.; Allen, P. Beyond organic and fair trade? An analysis of ecolabel preferences in the United States. Rural Sociol. 2010, 75, 244-269.

20. Masters, M.; Tikina, A.; Larson, B. Forest certification audit results as potential changes in forest management in Canada. For. Chron. 2010, 86, 455-460. 
21. Johansson, J.; Lidestav, G. Can voluntary standards regulate forestry?-Assessing the environmental impacts of forest certification in Sweden. For. Policy Econ. 2011, 13, 191-198.

22. Tysiachniouk, M. International environmental NGOs: Actors of ecological modernization in Russian forest sector. In Ecological Modernization of Forest Sector in Russia and USA; Tysiachniouk, M., Kulyasov, I., Pchelkina, S., Eds.; Research Chemistry Center of Saint-Petersburg State University: Saint-Petersburg, Russia, 2003; pp. 8-25.

23. Tysiachniouk, M. Forest certification in Russia. In Confronting Sustainability: Forest Certification in Developing and Transitioning Countries; Cashore, B., Gale, F., Meidinger, E., Newsom, D., Eds.; Yale School of Forestry and Environmental Studies, Publication Series: New Haven, CT, USA, 2006; pp. 261-295.

24. Voropaev, A. Itogi oprosa: WWF Rossii byet trevogu. (Survey Results: WWF Russia sounds the alarm (in Russian)). Ustoichivoe Lesoupravlenie 2011, 1, 42-43.

25. Ptichnikov, A.V.; Bubko, E.V.; Zagidullina, A.T. Dobrovolnaya lesnaya sertifikaciya [Voluntary forest certification]. Russian. Available online: http://www.fsc.ru/upload/fsc_ucheb.pdf (accessed on 10 January 2012).

26. Ulybina, O.; Fennell, S. Forest certification in Russia: Challenges of institutional development. Ecol. Econ. 2013, 95, 178-187.

27. Kulyasova, A. Trust as a strategy of interaction: Three logging companies in one district. For. Policy Econ. 2013, 31, 28-36.

28. Trishkin, M.; Lopatin, E.; Karjalainen, T. Assessment of motivation and attitudes of forest industry companies toward forest certification in northwestern Russia. Scand. J. For. Res. 2014, 29, 283-293. Available online: http://dx.doi.org/10.1080/02827581.2014.896938 (accessed on 5 September 2014).

29. All about Russian Forests. 2000. Sertifikat No 1 vedeniya ustoichivogo lesnogo chozjaistva—na Altae (First FSC Certificate Indicating Sustainable Forest Management Practices in Altay Region). In Russian. Available online: http://www.forest.ru/rus/sustainable_forestry/certification/ woodmark.html (accessed on 10 January 2012).

30. Forest Stewardship Council (FSC). List of Russian Companies Holding a Forest Management and Chain of Custody Certificates (from 3 March 2015). Available online: http://fsc.ru/ (accessed on 6 March 2014).

31. Programme for the Endorsement of Forest Certification (PEFC). PEFC Council Information Register. Available online: http://www.pefcregs.info/search1.asp (accessed on 6 March 2015).

32. Karvinen, S.; Välkky, E.; Gerasimov, Y.; Dobrovolsky, A. 2011. Northwest Russian Forest Sector in a Nutshell; Finnish Forest Research Institute, Vammalan Kirjapaion Oy: Sastamala, Finland, 2011; p. 138.

33. Hain, H. The Role of Voluntary Certification in Promoting Sustainable Natural Resource Use in Transitional Economies; Dissetationes Geographicae Universitatis Tartuensis: Tartu, Estonia, 2012; Volume 47, p. 79.

34. Capiroso, K.A.E. Legal and Sustainable? An exploratory analysis of the interactions between FSC and EU FLEGT forest regimes. Master's thesis. Department of Environmental Sciences Forest and Nature Conservation Policy Group Wageningen University and Research Centre: Wageningen, The Netherlands, 2011. 
35. EU (2010) Regulation (EU) No $995 / 2010$ of the European Parliament and of the Council of 20 October 2010, Laying down the Obligations of Operators Who Place Timber and Timber Products on the Market. Available online: http://ec.europa.eu/environment/forests/timber_regulation.htm\#rules (accessed on 10 January 2013).

36. European Comission (EC). Timber Regulation. Available online: http://ec.europa.eu/environment/ forests/timber_regulation.htm (accessed on 16 April 2014).

37. FL 415, 2013. Federal Law 415 adopted in Russian Federation on 28.12.2013 (In Russian). Available online: http://www.rg.ru/2013/12/30/drevesina-dok.html (accessed on 19 April 2014).

38. Shmatkov, N. Evropeyskiy rynok protiv nelegalnoy drevesiny [European market against illegal wood]. Sustain. For. Manag. 2011, 1, 15-26.

39. Transparency International. Corruption Perception Index 2014: Results. Available online: http://www.transparency.org/cpi2014/results (accessed on 12 January 2015).

40. LegalSource, 2013. NEPCon LegalSource Standard. Version 1. Available online: http://www.nepcon.net/files/resource_1/news/2013/2\%20FEB/NEPCon\%20LegalSource\%20Stan dard\%2008FEB13.pdf (accessed on 6 May 2013).

41. FSC CW Risk Assessment, 2013. Interpretation of Annex 2b of the Standard for Company evaluation of FSC Controlled Wood for Russian Federation. Available online: https://ic.fsc.org/download.nra-for-russia.1307.htm (accessed on 21 May 2014).

42. FSC Standard for Company Evaluation of FSC Controlled Wood. FSC-STD-40-005 (Version 2-1). Available online: https://us.fsc.org/preview.standard-for-company-evaluation-of-controlled-woodfsc-std-40-005v2-1en.a-198.pdf (accessed on 21 August 2014).

43. FSC Policy. Policy for the Association of Organizations with FSC (FSC-POL-01-004 V2-0). Available online: https://ic.fsc.org/preview.fsc-pol-01-004-v2-0-policy-for-the-association-oforganizations-with-fsc.a-490.pdf (accessed on 13 October 2014).

44. EFI, 2005. Impacts of Reduction of Illegal Logging in European Russia on EU and European Russia Forest Sector and Trade. EFI Technical report. Available online: http://www.efi.int/files/ attachments/publications/tr_19.pdf (accessed on 11 January 2014)

45. Gosbook. 2013. Joint State Automated Information System of Wood Flow Accounting and its Trading. Available online: http://www.gosbook.ru/node/83042 (accessed on 10 June 2014).

46. FSC Online Claim Platform, 2014. Available online: http://ocp-info.fsc.org/ (accessed on 28 July 2014).

47. Client Earth. Member state implementation of the EU Timber Regulation: The Basics. Available online: http://www.clientearth.org/201402282460/climate-and-forests/climate-forestspublications/member-state-implementation-of-the-timber-regulation-the-basics-2460 (accessed on 26 February 2014).

(C) 2015 by the authors; licensee MDPI, Basel, Switzerland. This article is an open access article distributed under the terms and conditions of the Creative Commons Attribution license (http://creativecommons.org/licenses/by/4.0/). 